\title{
Novel $N$-(4-Piperidinyl)benzamide Antimalarials with Mammalian Protein Farnesyltransferase Inhibitory Activity
}

\author{
Adina Ryckebusch, ${ }^{a}$ Pauline Gilleron, ${ }^{a}$ Régis Millet,${ }^{a}$ Raymond Houssin, ${ }^{a}$ Amélie Lemoine, ${ }^{a}$ \\ Nicole Pommery, ${ }^{a}$ Philippe Grellier, ${ }^{b}$ Christian Sergheraert, ${ }^{c}$ and Jean-Pierre Hénichart ${ }^{*}, a$ \\ ${ }^{a}$ Institut de Chimie Pharmaceutique Albert Lespagnol, EA 2692, Université de Lille 2; 3 rue du Professeur Laguesse, B.P. \\ 83, 59006 Lille, France: ${ }^{b}$ Museum National d'Histoire Naturelle, USM 0504; 61 rue Buffon, 75005 Paris, France: and \\ ${ }^{c}$ Institut de Biologie et Institut Pasteur de Lille, UMR CNRS 8525, Université de Lille 2; 1 rue du Professeur Calmette, B.P. \\ 447, 59021 Lille, France. $\quad$ Received February 7, 2005; accepted June 12, 2005
}

Protein farnesyltransferase of Plasmodium falciparum is a potential target in the treatment of malaria for which increased drug resistance is observed. The design, synthesis and evaluation of a series of $\mathrm{N}$-(4piperidinyl)benzamides is reported. The most potent compounds showed in vitro activity against the parasite at submicromolar concentrations.

Key words farnesyltransferase; malaria; Plasmodium falciparum; $\mathrm{N}$-(4-piperidinyl)benzamide derivative; inhibitor

Antimalarial drugs saved millions of lives during the 20th century. However, owing to the onset of drug resistance, there is now an urgent need to identify new drug targets in Plasmodium falciparum and to develop effective new antimalarial agents. ${ }^{1,2)}$ Prenylated proteins have been shown to function in important cellular processes including signal transductions. Among them, protein farnesyl transferase (PFT) has been a major target in the conception of new anticancer drugs. ${ }^{3)}$

In an effort to identify a new and more effective drug target, Chakrabarti ${ }^{4,5}$ found that the peptidomimetic L-745,631 (Chart 1) was the best inhibitor of $P$. falciparum PFT and also a good inhibitor of parasite growth.

This finding suggests the real potential of designing or identifying inhibitors of $P$. falciparum prenyl transferase as an approach to malaria therapy. In addition, several works have reported mammalian PFT inhibitors displaying potent antimalarial activities in vitro and more recently in vivo. ${ }^{6}$, Small inhibitors of mammalian FTase developed as anticancer drugs like BMS-214662 $2^{7-11)}$ are also effective inhibitors of $P$. falciparum growth. ${ }^{12,13)}$

\section{Results and Discussion}

Our work has focused on peptidomimetic inhibitors based on the $\mathrm{CA}_{1} \mathrm{~A}_{2} \mathrm{X}$ tetrapeptide, known to be responsible for interaction with the mammalian FTase, where the $\mathrm{A}_{1} \mathrm{~A}_{2}$ peptide is replaced by the structurally restricted $\mathrm{N}$-(4piperidinyl)benzamide scaffold. Initial studies ${ }^{14)}$ led us to compound 1 which possessed an $\mathrm{IC}_{50}$ (isolated enzyme FTase) as low as $22.8 \mathrm{~nm}$, but did not inhibit the proliferation of tumor cells in culture (Chart 2). More recently, ${ }^{15)}$ we synthesized a series of derivatives of compound $\mathbf{1}$, of general structure $\mathbf{2}$ which was the outcome of three structural modifi-
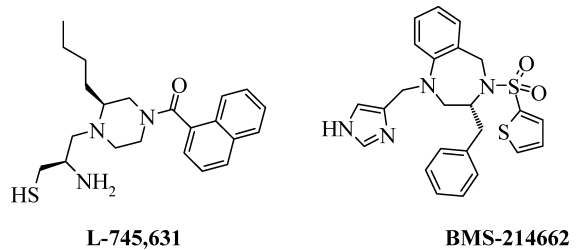

Chart 1 cations: (i) replacement of methioninate by phenylalaninate or isoleucinate $\left(\mathrm{R}_{1}\right)$ with the aim of increasing selectivity versus geranylgeranyl transferase, based on our previous results $^{14)}$ (ii) replacement of the cysteinyl moiety by a known metal chelator, i.e. (1-benzylimidazol-5-yl)methyl substituted in para position $\left(\mathrm{R}_{2}\right)$ of benzyl in order to increase cellular uptake (iii) reduction of the benzoyl group into benzyl $\left(\mathrm{R}_{3}\right)$ in order to introduce flexibility into this region of the molecule. Target compounds 15a-c, 16c, 17c, 18 were obtained by reductive amination between adequate imidazolylcarbaldehydes 8a-c and 4-aminopiperidines 12-14. The synthesis of 5-formylimidazoles $\mathbf{8 a}-\mathbf{c}$ was completed (Chart 3) in 5 steps according to a strategy ${ }^{16,17)}$ described for the preparation of regiochemically substituted imidazoleacetic esters: tritylation of $N_{1}$-imidazole (4), protection of primary alcohol as ester (5), benzylation of $N_{3}$ and detritylation of $N_{1}(\mathbf{6 a}-$ c). The aldehyde function was finally created by chemical oxidation of the hydroxymethyl group $(7 \mathbf{a}-\mathbf{c})$ resulting from hydrolysis of the ester $(\mathbf{6 a}-\mathbf{c})$. Piperidines 9-11 were also prepared (Chart 4) from reductive amination of $N$-Bocpiperidone with adequate $\alpha$-amino esters. Benzoylation and deprotection of piperidine (compounds 12-14, 18), possibly followed by reduction of benzoyl into benzyl for 12, was the last step before aminative reduction which yielded final compounds 15-17 and 19.

Antimalarial activities (Table 1) of piperidines 1, 15a-c, $16 \mathrm{c}, 17 \mathrm{c}$, and 19 range from 4.4 to $0.85 \mu \mathrm{M}$ with submicromolar activity for the most potent compound, 15b. Introduction of a trifluoromethyl substituent into the para of the benzyl group increases potency about 3-fold when compared to the non substituted compound 15a. The nature of the benzyl

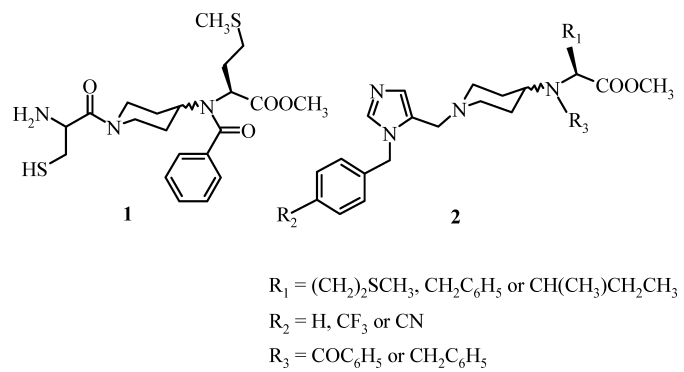

Chart 2 


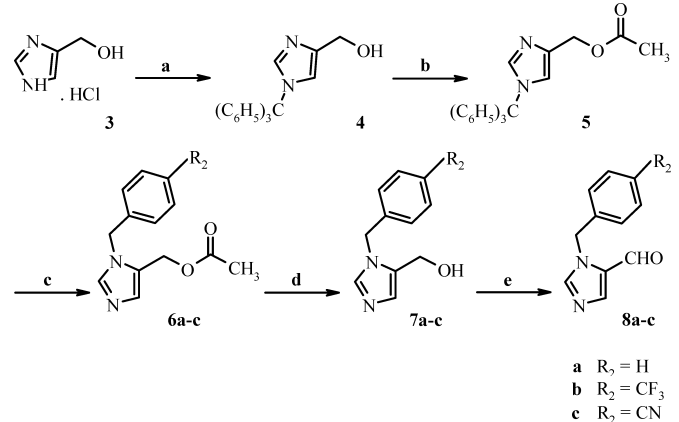

Reagents and conditions: (a) $\left(\mathrm{C}_{6} \mathrm{H}_{5}\right)_{3} \mathrm{CCl}, \mathrm{NEt}_{3}$, DMF, rt, $72 \mathrm{~h}, 71 \%$; (b) $\left(\mathrm{CH}_{3} \mathrm{CO}\right)_{2} \mathrm{O}$ pyridine, rt, $18 \mathrm{~h}, 84 \%$; (c) i) $(p) \mathrm{R}_{2}-\mathrm{C}_{6} \mathrm{H}_{4} \mathrm{CH}_{2} \mathrm{Br}$, EtOAc, $55^{\circ} \mathrm{C}, 24 \mathrm{~h}$; ii) $\mathrm{MeOH}$, reflux $18 \mathrm{~h}, 69-77 \%$ for $\mathbf{6 a}, \mathbf{b}$ or TFA, rt, $1 \mathrm{~h}, 57 \%$ for $\mathbf{6 c}$; (d) $2 \mathrm{~N} \mathrm{NaOH}, \mathrm{MeOH}, \mathrm{rt}, 0.5-2 \mathrm{~h}$, $36-99 \%$; (e) $\mathrm{MnO}_{2}$, dioxane, $30-40{ }^{\circ} \mathrm{C}, 3 \mathrm{~h}, 70-97 \%$.

Chart 3

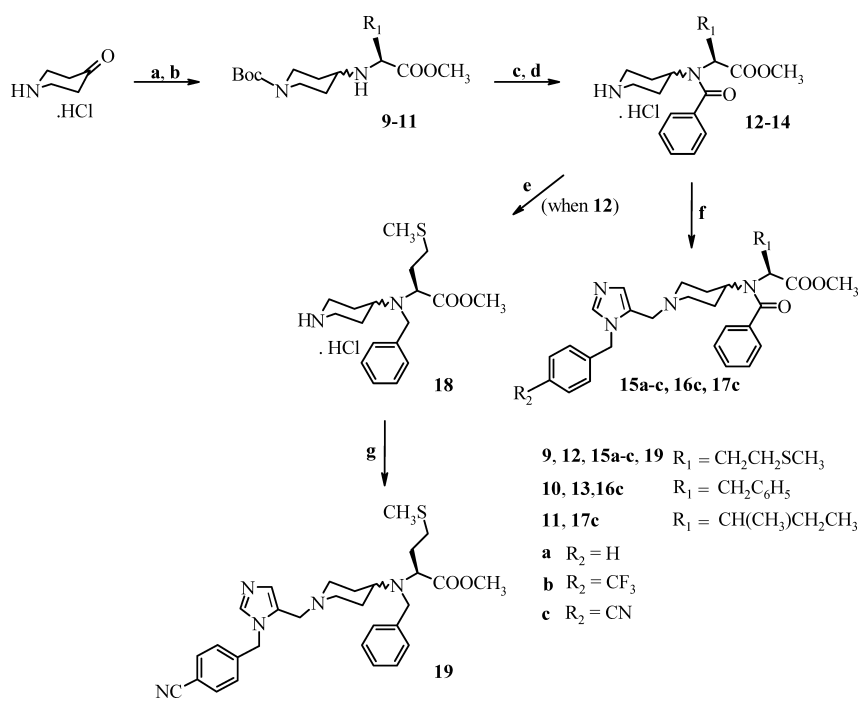

Reagents and conditions: (a) $\mathrm{Boc}_{2} \mathrm{O}$, DIEA, dioxane $/ \mathrm{H}_{2} \mathrm{O}(4: 1)$, rt, $24 \mathrm{~h}, 75 \%$; (b) $\mathrm{H}-$ (Met, Phe or Ile) $-\mathrm{OCH}_{3}, \mathrm{NEt}_{3}, \mathrm{NaBH}_{3} \mathrm{CN}, \mathrm{MeOH}, 50^{\circ} \mathrm{C}, 48 \mathrm{~h}, 40-68 \%$; (c) Benzoyl chloride, $\mathrm{NEt}_{3}, \mathrm{CH}_{2} \mathrm{Cl}_{2}, 0^{\circ} \mathrm{C}, 24 \mathrm{~h}, 30-55 \%$; (d) $\mathrm{HCl} / \mathrm{MeOH}, \mathrm{rt}, 18 \mathrm{~h}, 95 \%$; (e) i) $\mathrm{BH}_{3}$.THF, THF, $0{ }^{\circ} \mathrm{C}, 18 \mathrm{~h}$; ii) $6 \mathrm{~N} \mathrm{HCl}, \mathrm{H}_{2} \mathrm{O}$, reflux, $10 \mathrm{~min}, 30 \%$; (f) i) $8 \mathbf{a}-\mathbf{c}$, $\mathrm{NEt}$, $\mathrm{MeOH}$; ii) $\mathrm{NaBH}_{3} \mathrm{CN}, \mathrm{MeOH}, 50{ }^{\circ} \mathrm{C}, 18 \mathrm{~h}, 42-52 \%$; (g) i) $8 \mathbf{c}, \mathrm{NEt}_{3}, \mathrm{MeOH}$; ii) $\mathrm{NaBH}_{3} \mathrm{CN}, \mathrm{MeOH}, 50{ }^{\circ} \mathrm{C}, 18 \mathrm{~h}, 47 \%$.

Chart 4

Table 1. Biological Evaluation of Compounds $1, \mathbf{1 5 a}-\mathbf{c}, \mathbf{1 6 c}, \mathbf{1 7} \mathbf{c}$, and 19<smiles>[R]c1ccc(Cn2cncc2CN2CCC(N([R])C([R])C(=O)OC)CC2)cc1</smiles>

substituent is important, as replacement of $\mathrm{CF}_{3}$ by $\mathrm{CN}$ lowers potency about 3-fold (compound 15c). This result suggests that lipophilicity at this region of the molecule could have an important role in antimalarial activity. Replacement of the benzyl-4H-imidazol-4-ylmethyl moiety of compound 15a by a cysteinyl residue (compound $\mathbf{1}$ ) at the piperidinyl nitrogen increased antimalarial activity, which could also be attributed to stronger lipophilicity of the imidazolyl fragment compared to that of the cysteinyl one. Replacement of methioninate in compound $15 \mathrm{c}$ by other amino acid residues such as phenylalaninate (16c) or isoleucinate (17c) led to an increase in antimalarial activity, as high as 2 -fold in the case of $\mathbf{1 7 c}$. Aromaticity and greater lipophilicity in this region of the molecule seem to be favourable to antimalarial potency. Reduction of benzamide into benzylamine decreases antimalarial activity (15c vs. 19). As previously seen for other series of FTase mammalian inhibitors with potent antimalarial activities, ${ }^{4,18,19)}$ no correlation can be observed between the two biological activities. The most potent inhibitor of FTase in the series (19) displays the lowest antimalarial activity. On the other hand, the most potent antimalarial derivative, 15b, also displays good inhibition activity on FTase whereas compound 15a, possessing the lowest FTase inhibition, also displays low antimalarial activity. Taken together, these results suggest that in the set of compounds reported here, inhibitory activity of mammalian FTase is not sufficient to explain the antimalarial activities observed. Several works ${ }^{16,18,19)}$ suggest that the active-site recognition properties of malarial FTase should be different from those of the mammalian enzyme. This difference could partly account for the lack of correlation noted between the two activities. However, a more recent work $^{25)}$ suggests that the active-site residues of the farnesyltransferase of $P$. falciparum and rat are nearly identical despite low overall sequence identity due to several additional external loops of the P. falciparum enzyme. Except for structural microscopic differences between the two enzymes, there are other factors which could account for the differences noted. Pharmacological properties such as lipophilicity or weak basic character could be involved in cellular uptake inside the parasite. Additional mechanisms cannot be excluded such as complexation of imidazole moiety with ferriproto-

\begin{tabular}{|c|c|c|c|c|c|c|}
\hline \multirow{2}{*}{ Compd. } & \multirow{2}{*}{$\mathrm{R}_{1}$} & \multirow{2}{*}{$\mathrm{R}_{2}$} & \multirow{2}{*}{$\mathrm{R}_{3}$} & \multicolumn{2}{|c|}{$\mathrm{IC}_{50}^{a, b)}(\mathrm{nM})$} & \multirow{2}{*}{$\begin{array}{c}\mathrm{IC}_{50}^{22)}(\mu \mathrm{M}) \\
\text { P. falciparum }\end{array}$} \\
\hline & & & & FTase $^{c)}$ & GGTase- $1^{c}$ & \\
\hline $\mathrm{CQ}^{d)}$ & - & - & - & $\mathrm{Nd}^{e)}$ & $\mathrm{Nd}$ & $0.13 \pm 0.03$ \\
\hline 1 & - & - & - & $22.8 \pm 2.1$ & $>100$ & $1.6 \pm 0.3$ \\
\hline $15 a$ & $\left(\mathrm{CH}_{2}\right)_{2} \mathrm{SCH}_{3}$ & $\mathrm{H}$ & $\mathrm{COC}_{6} \mathrm{H}_{5}$ & $397 \pm 84$ & $\mathrm{Nd}$ & $2.9 \pm 0.9$ \\
\hline $15 b$ & $\left(\mathrm{CH}_{2}\right)_{2} \mathrm{SCH}_{3}$ & $\mathrm{CF}_{3}$ & $\mathrm{COC}_{6} \mathrm{H}_{5}$ & $43.9 \pm 4.2$ & $\mathrm{Nd}$ & $0.85 \pm 0.14$ \\
\hline $15 \mathrm{c}$ & $\left(\mathrm{CH}_{2}\right)_{2} \mathrm{SCH}_{3}$ & $\mathrm{CN}$ & $\mathrm{COC}_{6} \mathrm{H}_{5}$ & $4.60 \pm 2.36$ & $>2000$ & $3.0 \pm 0.9$ \\
\hline $16 c$ & $\mathrm{CH}_{2} \mathrm{C}_{6} \mathrm{H}_{5}$ & $\mathrm{CN}$ & $\mathrm{COC}_{6} \mathrm{H}_{5}$ & $22.0 \pm 6.6$ & $>2000$ & $7.0 \pm 0.1$ \\
\hline $17 \mathrm{c}$ & $\mathrm{CH}\left(\mathrm{CH}_{3}\right) \mathrm{CH}_{2} \mathrm{CH}_{3}$ & $\mathrm{CN}$ & $\mathrm{COC}_{6} \mathrm{H}_{5}$ & $32.7 \pm 3.8$ & $>2000$ & $1.4 \pm 0.4$ \\
\hline 19 & $\left(\mathrm{CH}_{2}\right)_{2} \mathrm{SCH}_{3}$ & $\mathrm{CN}$ & $\mathrm{CH}_{2} \mathrm{C}_{6} \mathrm{H}_{5}$ & $2.35 \pm 0.48$ & $>2000$ & $4.4 \pm 0.1$ \\
\hline
\end{tabular}

a) Values are means of three determinations. b) See refs. 15, 20,21. c) Mammalian enzyme. d) Chloroquine. e) Not determined. 
Table 2. Antiproliferative Effects of 4-Aminopiperidine FTIs on L-1210 and DLD-1 Cell Lines

\begin{tabular}{ccc}
\hline \hline & \multicolumn{2}{c}{$\mathrm{IC}_{50}{ }^{a}{ }^{a}(\mu \mathrm{M})$} \\
\cline { 2 - 3 } Compd. & $\mathrm{L}-1210$ & $\mathrm{DLD}-1$ \\
\hline $\mathbf{1}$ & $>10(>6.2)^{b)}$ & $18.1 \pm 2.3(11)$ \\
$\mathbf{1 5 a}$ & $>10(3.5)$ & $27.1 \pm 6.6(9.3)$ \\
$\mathbf{1 5 b}$ & $>10(>12)$ & $63.1 \pm 18.6(74)$ \\
$\mathbf{1 5 c}$ & $0.020 \pm 0.006(0.007)$ & $9.20 \pm 2.47(3.0)$ \\
$\mathbf{1 6 c}$ & $4.95 \pm 0.29(0.7)$ & $7.74 \pm 3.62(1.6)$ \\
$\mathbf{1 7 c}$ & $6.62 \pm 0.32(4.7)$ & $26.5 \pm 6.3(19.0)$ \\
$\mathbf{1 9}$ & $3.95 \pm 0.22(0.9)$ & $12.9 \pm 3.8(2.9)$ \\
\hline
\end{tabular}

a) See ref. 27. b) The ratio $\mathrm{IC}_{50 \text { compound }} / \mathrm{IC}_{50 \text { Pfalciparum }}$ is given in parentheses.

porphyrin IX (FP) reported for potent in vitro imidazole antimalarials, ${ }^{26)}$ which could also help to explain the differences noted.

Cytotoxicities on mammalian cells (Table 2) were evaluated on two selected cell lines (murine leukemia cell line L1210 and human colon cell line DLD-1 which expresses KRas isoform in wild type) in order to determine the ratio between antiproliferative effects of compounds and in vitro activity against $P$. falciparum. The compounds have $\mathrm{IC}_{50}$ values against L-1210 and DLD-1 in the micromolecular range, except for 15c (on L-1210). As seen with the direct comparison of the $\mathrm{IC}_{50}$ values, there is no significant relationship. For example, 15b has better activity for $P$. falciparum than for L1210 and DLD-1 cell lines, which was not observed for $\mathbf{1 5 c}$. This shows that it is possible to develop antimalarial drugs without cytotoxic side effects.

In conclusion, new $N$-(4-piperidinyl)benzamide derivatives have been designed as FTase mammalian inhibitors displaying significant antimalarial micromolar and submicromolar activities. The results obtained demonstrate that requirements for FTase inhibition and antimalarial activity on the $\mathrm{N}-(4-$ piperidinyl)benzamide core are not exactly similar, suggesting that selective inhibition of parasitic growth over mammalian FTase inhibition should be possible. This study enables us to highlight a new antimalarial lead compound, $\mathbf{1 5 b}$. Further modulations to this compound are ongoing in order to optimize its antiparasitic activity. The first goal consists in combining the presence of diverse hydrophobic and bulky $\mathrm{R}_{1}$ substituents with the replacement of methionine by isoleucine or other lipophilic groups. This work, together with other previous studies, shows that despite the absence of recombinant $P$. falciparum enzyme, the screening of FTase mammalian inhibitors on parasite growth can provide a number of new antimalarial leads.

\section{References and Notes}

1) Ridley G. R., Nature (London), 415, 686-692 (2002).

2) Fidock D. A., Rosenthal P. J., Croft S. L., Brun R., Nwaka S., Nat. Rev. Drug Discov., 3, 509-520 (2004).

3) Caponigro F., Casale M., Bryce J., Expert Opin. Investig. Drugs, 12 943-954 (2003)

4) Chakrabarti D., Azam T., DelVecchio C., Qiu L., Park Y.-i., Allen C. M., Mol. Biochem. Parasitol., 94, 175-184 (1998).

5) Chakrabarti D., Da Silva T., Barger J., Paquette S., Patel H., Patterson S., Allen C. M., J. Biol. Chem., 277, 42066-42073 (2002).

6) Carrico D., Ohkanda J., Kendrick H., Yokoyama K., Blaskovich M. A., Bucher C. J., Buckner F. S., Van Voorhis W. C., Chakrabarti D., Croft S. L., Gelb M. H., Sebti S. M., Hamilton A. D., Bioorg. Med. Chem., 12, 6517-6526 (2004).

7) Reid T. S., Beese L. S., Biochemistry, 43, 6877-6884 (2004).
8) Mackay H. J., Hoekstra R., Eskens F. A., Loos W. J., Crawford D., Voi M., Van Vreckem A., Evans T. R., Verweij J., Clin. Cancer Res., 10, $2636-2644$ (2004).

9) Ryan D. P., Eder J. P., Jr., Puchlaski T., Seiden M. V., Lynch T. J., Fuchs C. S., Amreim P. C., Sonnichsen D., Supko J. G., Clark J. W., Clin. Cancer Res., 10, 2222-2230 (2004).

10) Johnston S. R., IDrugs, 6, $72-78$ (2003).

11) Hunt J. T., Ding C. Z., Batorsky R., Bednarz M., Bhide R., Cho Y., Chong S., Chao S., Gullo-Brown J., Guo P., Kim S. H., Lee F. Y., Leftheris K., Miller A., Mitt T., Patel M., Penhallow B. A., Ricca C., Rose W. C., Schmidt R., Slusarchyk W. A., Vite G., Manne V., J. Med. Chem., 43, 3587-3595 (2000).

12) Windsor W. T., Weber P. C., Wang J. J.-S., Strickland C. O., Njoroge F. G., Guzi T. J., Girijavallabhan V. M., Ferreira J. A., Desai J. A., Cooper A. B., Gelb M., PCT Int. Appl., WO 02/056884 (2002) [Chem. Abstr., 137, 125178 (2002)].

13) Windsor W. T., Weber P. C., Strickland C. O., Girijavallabhan V. M., PCT Int. Appl., WO 02/080895 (2002) [Chem. Abstr., 137, 304744 (2002)]

14) Houssin R., Pommery J., Salaün M.-C., Deweer S., Goossens J.-F., Chavatte P., Hénichart J.-P., J. Med. Chem., 45, 533-536 (2002).

15) Millet R., Domarkas J., Houssin R., Gilleron P., Goossens J.-F., Chavatte P., Logé C., Pommery N., Pommery J., Hénichart J.-P., J. Med. Chem., 47, 6812-6820 (2004).

16) Anthony N. J., Gomez R. P., Schaber M. D., Mosser S. D., Hamilton K. A., O’Neill T. J., Koblan K. S., Graham S. L., Hartman G. D., Shah D., Rands E., Koh N. E., Gibbs J. B., Oliff A. I., J. Med. Chem., 42, 3356-3368 (1999).

17) Williams T. M., Bergman J. M., Brashear K., Breslin M. J., Dinsmore C. J., Hutchinson J. H., MacTough S. C., Stump C. A., Wei D. D., Zartman C. B., Bogusky M. J., Culberson J. C., Buser-Doepner C., Davide J., Greenberg I. B., Hamilton K. A., Koblan K. S., Kohl N. E., Liu D., Lobell R. B., Mosser S. D., O’Neill T. J., Rands E., Schaber M. D., Wilson F., Senderak E., Motzel S. L., Gibbs J. B., Graham S. L., Heimbrook D. C., Hartman G. D., Oliff A. I., Huff J. R., J. Med. Chem., 42, 3779-3784 (1999)

18) Ohkanda J., Lockman J. W., Yokoyama K., Gelb M. H., Croft S. L., Kendrick H., Harrell M. I., Feagin J. E., Blaskovich M. A., Sebti S. M., Hamilton A. D., Bioorg. Med. Chem. Lett., 11, $761-764$ (2001).

19) Wiesner J., Ortmann R., Mitsch A., Wißner P., Sattler I., Jomaa H., Schlitzer M., Pharmazie, 58, 289-290 (2003).

20) Khan S. G., Mukthar H., Agarwal R., J. Biochem. Biophys. Methods, 30, 133-144 (1995).

21) Cassidy P. B., Dolence J. M., Poulter C. D., Methods Enzymol., 250, $30-43$ (1995)

22) In vitro $P$. falciparum culture and drug assay. $P$. falciparum strains were maintained continuously in culture on human erythrocytes. ${ }^{23)}$ In vitro antiplasmodial activity was determined using a modification of the semi-automated micro-dilution technique. ${ }^{24)}$ Plasmodium falciparum chloroquine-resistant (FcB1R/Colombia) strains were used in sensitivity testing. Stock solutions of chloroquine diphosphate and test compounds were prepared in sterile distilled water and DMSO, respectively. Drug solutions were serially diluted with culture medium and introduced to asynchronous parasite cultures $(0.5 \%$ parasitemia and $1 \%$ final hematocrite) on plates comprising 96-well plates for $24 \mathrm{~h}$ at $37^{\circ} \mathrm{C}$ prior to the addition of $0.5 \mu \mathrm{Ci}$ of $\left[{ }^{3} \mathrm{H}\right]$ hypoxanthine (1 to $5 \mathrm{Ci} / \mathrm{mmol}$; Amersham, Les Ulis, France) per well, for $24 \mathrm{~h}$. The growth inhibition of each drug concentration was determined by comparison of the radioactivity incorporated into the treated culture with that in the control culture (without drug) maintained on the same plate. $\mathrm{IC}_{50}$ was obtained from the drug concentration-response curve and the results were expressed as mean \pm standard deviations, determined from several independent experiments. The DMSO concentration never exceeded $0.1 \%$ and did not inhibit parasite growth.

23) Trager W., Jensen J. B., Science, 193, 673-675 (1976)

24) Desjardins R. E., Canfield C. J., Haynes J. D., Chulay J. D., Antimicrob Agents Chemother, 16, 710-718 (1979).

25) Wiesner J., Kettler K., Sakowski J., Ortmann R., Katzin A. M., Kimura E. A., Silber K., Klebe G., Jomaa H., Schlitzer M., Angew. Chem., Int Ed. Engl., 43, 251-254 (2004).

26) Lew V. L., Tiffert T., Ginsburg H., Trends Parasitol., 18, 156 (2002).

27) Cell culture and growth assays. DLD-1 (human colon adenocarcinoma transformed by K-Ras oncogene) and L-1210 (mouse lymphocytic leukaemia) were cultured in RPMI medium with $10 \%$ fetal calf serum. Cells were allowed to grow for $72 \mathrm{~h}$ in 96 -microwell plates and then treated with a range of inhibitor concentrations for $72 \mathrm{~h}$ (final $1 \%$ DMSO concentration). Cell growth was measured by means of the colorimetric MTT assay. 